\title{
China's Assertiveness in the South China Sea: Have ASEAN's Endeavors in Establishing Regional Order Truly Failed?
}

\author{
Bama Andika Putra ${ }^{1}$ \\ ${ }^{1}$ Melbourne School of Government, University of Melbourne, Melbourne, Australia \\ Correspondence: Bama Andika Putra, Melbourne School of Government, University of Melbourne, Melbourne, \\ Australia. Tel: 62-449-649-238. E-mail: bputra@unimelb.edu.au
}

Received: July 18, 2015 Accepted: August 28, 2015 Online Published: November 29, 2015

doi:10.5539/jpl.v8n4p178 URL: http://dx.doi.org/10.5539/jpl.v8n4p178

This research was funded by a grant from the Indonesia Endowment Fund for Education (LPDP) of the Republic of Indonesia.

\begin{abstract}
The territorial disputes in the South China Sea have become the major flashpoints of both potential and existing conflicts in Asia. With claimant states from both China and member states of ASEAN, the aggressive military gestures of the claimant states have led to a myriad number of confrontations throughout the years. The inevitability of ASEAN being in the center of the disputes, have led many critics towards the regional organization on its capacity to establish any significant changes towards the dynamics of the South China Sea disputes. This research argues the opposite of the existing academic literatures, which views ASEAN as not an ideal actor in facing the fast paced dynamics of the South China Sea conflicts. It argues of ASEAN's ability and capacity to persuade China into some forms of compromises into its policy, reflected through its defined position of a conflict management institution throughout the South China Sea crisis. The research thus argues how there is an existing misperception of ASEAN's conflict management endeavors with the occurrence of China's recent assertive gestures, ASEAN's ability in instilling cooperative values and confidence building measures among conflicted states, and relevance of ASEAN's multilateralism measures despite of China's historical stance of bilateral means of conflict resolution in regards to the South China Sea conflict.
\end{abstract}

Keywords: regionalism, ASEAN, conflict management, territorial disputes, international borders, China, southeast Asia, institutionalism

\section{Introduction}

With decades of tensions between China and the claimant states of ASEAN members, the South China Sea remains one of the most major flashpoint for potential conflicts in Asia. Though all claimants are parties to the UNCLOS (United Nations Convention on the Law of the Sea) 1982, the overlapping sovereignty claims of each of the claimant's Economic Exclusive Zone (EEZ) remains an issue that have progressed on a relatively slow pace. Grouped into 3 archipelagos (Paracels, Spratlys, and Scarborough Shoal) consisting of approximately 250 small islands (Chalk, 2014), the South China Sea is of great significance for the claimant states, as the seas represent both a major shipping route and an extension of sovereign territorial area.

The foundational basis of China's claims over the seas is based on its 11-dashed line map, which encompasses a majority of the South China Seas. Officially published In 1947 by the then Chinese Nationalist Party Kuomintang, China's claims over the seas is primarily based on its historical claims known to have been evident since the ancient times (Jinming, 2012). In 2009, China submitted its '9-dashed lines' to the UNCLOS commission regarding the limits of the continental shelf, which draws the dashes closer to the coasts of the neighboring states (in comparison to the 1947 map) (US Department of State, 2014). Though the 9 dashed lines is defined as illegal under the UNCLOS as it extends beyond the 12 nautical miles of China, the state continuously is persistent with its claims, and continues to be assertive in facing the other claimants over the seas.

Extended towards the Exclusive Economic Zone of ASEAN member states (Philippines, Vietnam, Brunei, Malaysia, and to a small extent Indonesia), these states have faced China's assertiveness in the South China Sea 
for decades long. Several most prominent disputes in the South China Sea include China's seizure of the Paracel Islands in 1974, the 1988 deadly clash that killed 70 Vietnamese sailors, and the 1995 Chinese occupation of the Philippines-claimed Mischief Reef (Fravel, 2011). These series of events have led ASEAN (Association of Southeast Asian Nations) to take part by managing tensions in the region. Initially demanded by Philippines after China's occupation of the Mischief Reef in1995, ASEAN's early involvement in the South China Sea is linked to the decision of negotiating a 'Code of Conduct' between ASEAN member states and China (Thayer, 2013), aimed to provide practical restrictions of conduct that could be taken in the disputed islands of the South China Sea.

China throughout the years has been persistent with its historical claims over the seas, and shows an insignificant amount of compromises. Opposition to the aim of peaceful resolution of the disputes, China's aggression has yet to show a decline since the escalated wars in 1974, 1988 and 1995 (Chen, 2014). It is worth noting that China has shown a military gesture of assertiveness in order to realize its outrageous claims over the seas. 2 of the most prominent assertive actions in the present time is China's placement of an oil-drilling rig (the HYSY-981) located 120 miles from Vietnam's coast in May 2014 (withdrew in July 2015) (Leaf, 2014), and the current land reclamations in the Spratly Islands, consisting of facilities which includes airstrips and communication buildings (Rapp-Hooper, 2015).

As of ASEAN, an immense pessimism exists towards the regional organization's capacity to create any significant changes in the disputed South China Sea. This research will thus argue how ASEAN's non-binding agreements and voluntary participations in the measures aimed in maintaining order in the South China Sea, have been discredited and undermined by existing academic literatures which aims to evaluate ASEAN's role in the South China Sea disputes. Based on that fundamental flaw, this research shall argue of ASEAN's significant contributions on its role in managing the tensions in the South China Sea, leading China to adopt confidence building measures, and have in numerous times been self-restraint in its assertive actions in the region.

\section{ASEAN's Model of Conflict Management, and the Establishment of Regional Order}

Established in 1967, ASEAN is fundamentally aimed to promote economic growth, social progress, cultural development, and maintain the peace and stability in the region. Differing itself with other regional organizations, the history of traumatic colonial rule of ASEAN state members led to the formation of ASEAN principles to respect the sovereignty of states. This is further reflected through the implementation of Non-interference as basis of the organization's conduct. Not only that, the Treaty of Amity and Cooperation (TAC) of 1976 outlines ASEAN's fundamental principles to also include: (1) respect over sovereignty, (2) right to be free from external interference, (3) a peaceful manner of solving disputes, (4) renunciation of the use of force, and (5) effective cooperation among members (ASEAN, 2005). Needless to say, that the affectivity of a regional organization such as ASEAN highly depends on the state's commitment in running the organization. One thing that needs to be outlined is the organizations priority to achieve regional order in the region.

Lake and Morgan defines regional order in 1997, as "the mode of conflict management within the regional security complex" (Lake \& Morgan, 1997). In achieving regional order, measures that could be taken include integration, pluralistic, security communities, collective security, and power politics (Lake \& Morgan 1997). ASEAN specifically leans to the idea of multilateralism, aimed to balance the power politics of the hegemonic states in the region (management of unequal power). Regional order is thus achieved through multilateral initiatives placing ASEAN at the core of multilateral dialogues, initiatives, institutions, and forums.

Conflict management thus is not a new concept for ASEAN. Since its establishment, 39 maritime boundary agreements took place in the region $(\mathrm{Ba}, 2014)$. ASEAN as an organization places the issue of territorial disputes as a dynamic which undermines the regional stability, therefore has been active to manage tensions, helping the state actors involved to find resolutions out of such conflicts. As a term used to cover the positive conflict handling, conflict management is known as a more limited way to the settlement and containment of violent conflict (Ramsbotham, Woodhouse \& Miall, 2011). Conflict management thus differs itself with conflict resolution which by definition implies to the reduction, elimination or termination of conflict (Rahim, 2002). In this case, various actions conducted by China that reflects self-restraint and willingness to voluntarily compromise its assertive and hardened position in the South China Seas only proves of ASEAN's success in its role of managing the conflict.

There have been numerous academic literatures outlining ASEAN's role in regards to the South China Sea. To conclude, the academic literatures have basically perceived ASEAN as not the ideal actor that could make significant differences to the conflict happening in the South China Sea. Fravel (2011) explained how the various agreements between ASEAN and China throughout the years have only been symbolic, and lacking substantive 
values. Emmers (2010) went further to tackle ASEAN's conflict management model, by arguing that conflict management efforts of ASEAN have not been able to deter the growing assertive behavior of China, therefore fails in managing the unequal power distribution in the South China Sea. This research shall argue the opposite, in which ASEAN's efforts pertained to conflict management of the South China Sea have eventually created patterns of Chinese compromise and self-restraint, which in actuality reflects not of ASEAN's failure, but its success in managing the tensions in the region. This research shall conclude the opposite, in which ASEAN's endeavors in establishing regional order specifically towards the case of South China Sea have been progressive, and how ASEAN still acts as a great potential actor for the South China Sea conflict management.

\section{ASEAN's Conflict Management Role on the South China Sea Dispute}

Despite the pessimism towards ASEAN on its capacity in handling the South China Sea, they still are able to exert essential elements of conflict management. Conflict management in itself is a crucial step for concluding ideal outcomes on the dispute, such as the completion of the Code of Conduct on South China Sea (COC) negotiations, and the eventual peaceful resolution among claimant states. In doing so, this research shall start out by elaborating the existing misperceptions of mixing ASEAN's conflict management endeavors with the occurrence of China's assertive behaviors in the South China Sea. Further more, in explaining the specific success of ASEAN's conflict management role, this research shall analyze China's compromises over its assertiveness in the South China Sea as the success of ASEAN, which instilled values of cooperation and confidence building, and how ASEAN's multilateralism still is relevant despite China's preference for a bilateral based conflict resolution.

\subsection{The Existing Misperceptions Mixing ASEAN's Conflict Management Endeavors with the Occurrence of China's Assertive Behavior in the South China Sea}

The idea of misinterpreting China's act of assertiveness to be caused by a particular actor is a common phenomenon. Despite only involving 5 claimant states, the South China Sea dispute has been severely internationalized, opening possibilities for other external actors to be involved by interfering in the dispute. Externalities, or the involvement of external actors which do not hold any claims over the seas, provides an immense difficulty in analyzing whether China's assertive actions in the South China Sea is a response of a particular actor, or another.

It is crucial to note, that ASEAN is actually also categorized as an external actor, in which China perceives that ASEAN should not be involved in the conflicts as it should only involve individual claimant states of ASEAN, not the overall organization. But considering that China became parties of the Treaty of Amity and Cooperation (TAC) in 2003, and the Declaration on the Conduct of Parties in the South China Sea (DOC) in 2002, the presence of ASEAN which aims to somehow instill values of cooperation and peaceful measures to resolve the conflict, can be fully understood by China. This fact though does not reflect the involvement of external actors such as the US, and how often times it is the actions of individual claimant states that results to China's assertiveness in the South China Sea.

Conflict management thus for ASEAN is defined in different initiatives compared to external actors such as the US. It is essential to outline that a high number of China's assertive behaviors in the South China Sea can be attributed to the US's reorientation of its foreign policy to focus on the Asia-Pacific under the Obama Administration (better known as the 'Asian Pivot') (Campbell \& Andrews, 2013). The policy is perceived by China as an act to contain its growing hegemonic power in the region, and seen as a threat towards China's regional ambitions (Emmers, 2015). The pivot has never been taken lightly by China, in which US is seen to have emboldened its allies (which are claimants in South China Sea dispute) to take harder stance against China (Keck, 2014). Thus the level of suspiciousness towards the US presence and involvement in the dispute is prominently high for China, and it seems that any actions of the US in the South China Sea is perceived as a national threat towards China's sovereignty claims. A clear example of this is the recent US use of surveillance aircrafts to monitor the situation in South China Sea, in which the Chinese Foreign Ministry spokesman Hong Lei responded by stating that the action was, “...irresponsible, dangerous, and detrimental to regional peace and stability" (Wee \& Brunsstrom, 2015). Not long after this incident (which occurred in May 2015), China responded with the placement of mobile artillery weapons systems on a reclaimed island (Reuters, 2015).

Another dynamic worth understanding in the South China Sea, is that actions of individual claimant states of ASEAN have eventually led to the slower progress of negotiations, and an increased assertiveness of China. Though Vietnam, Philippines, Brunei, and Malaysia are all claimants in the South China Sea, Vietnam and Philippines have been the most vocal about the dispute. Actions conducted by Philippines and Vietnam throughout the years (especially the last 5 years) has contributed immensely towards the overall assertiveness of 
China, and its hard lined stance on the dispute. 2 events which immensely contributed towards this were: (1) January 2013 Philippines initiating an International arbitration process under the UNCLOS (Dutton, 2013), and (2) Vietnam's internationalization of the issue by seeking US support in the 2010 ARF meeting (eventually led to the historical speech of Hillary Clinton, stating of US's national interest in the South China Sea based on freedom of navigation) (Collinson \& Roberts, 2015). Besides that, a series of maritime stand offs and sinking of fishing ships have been present in the past 5 years, reflecting China's upmost assertive behavior in facing the competing claimant states. The unilateral actions thus should be highly considered as one of the main factors of China's assertiveness in the South China Sea. But this reality, does not simply conclude that ASEAN is no longer relevant, as these cases only describes of ASEAN's more difficult position to reach a consensus on conflict management measures, as China's behavior toward the policies of ASEAN is highly dependent upon the current dynamics of the multiple actors involved in the South China Sea dispute.

\subsection{ASEAN's Role in Instilling Cooperative Values and Confidence Building Measures}

To an extent, China has not shown an absolute policy of assertiveness in the South China Sea. As explained earlier, sudden actions of assertiveness can be attributed to the unilateral decisions of actors involved in the dispute. But in several cases, China has shown to ASEAN and the International community, its willingness to engage on peaceful negotiations and talks to find outcomes of the South China Sea dispute. To start of, it is vital to understand China's position in the region.

Perceived as the emerging global superpower, China's presence in Asia is one that is dominant. For years, China has been known as a state that would show very little compromises when it gets to the issue of territorial disputes, reflected through its highly assertive gesture against Philippines and Vietnam during the Cold war over the South China Sea dispute, and in other territorial disputes such as over the Senkaku Islands since the 1970s. Though established in 1967, the initial involvement of ASEAN on the South China Sea dispute was linked to the 1995 China occupation of the Philippines claimed Mischief Reef, just years before the eventual outcome of the 2002 DOC (Severino, 2010). Though at first aimed to directly reach a consensus on a more legally binding COC, we cannot ignore the significance of ASEAN's capacity to include China as a party of the DOC. China being part of the DOC reflects the fact that the state still sees the prominent need to negotiate a particular conduct/ outcome with the other competing claimant states on the South China Sea dispute.

Despite the fact that China had the capacity to continue its assertiveness by continuously violating the EEZ of the claimant states, China decided to back down, and be involved in the negotiations under ASEAN's umbrella. This shows that China is 'image-conscious,' therefore would voluntarily self-restrain itself from continuing such assertive gestures, and decided to engage with ASEAN's conflict management policies which prioritizes peaceful resolution, and the respect of a nation's sovereignty. Not only that, the involvement of ASEAN in the South China sea by managing the conflicts, have positioned China to reassure its neighboring countries in Southeast Asia that its presence there cannot be simply generalized by its actions in the South China Sea. The reassurance policies of China includes the signing of the 2002 ACFTA (ASEAN-China Free Trade Agreement), establishment of the Asian Infrastructure Investment Bank (AIIB) in 2014, $21^{\text {st }}$ century Maritime Silk Road, and many more.

Though little progress has been done concerning the territorial boundaries of the South China Sea, cooperation between ASEAN and China have been intensive in the last couple of years. The intensive cooperation is prominently evident in 2015, which the Chinese leaders have announced as the year of ASEAN-China Maritime Cooperation. Based on the initial China-ASEAN Maritime Cooperation Fund announced at the $14^{\text {th }}$ China ASEAN Summit and Commemorative summit November 2011 (ASEAN, 2014), the year is aimed to facilitate numerous practical cooperation between ASEAN and China, specifically on the sector of maritime. Maritime cooperation defined here brings great significance, considering that the cooperation takes in the form of marine economy, maritime connectivity, research, and safety/ security (Parameswaran, 2015). China's announcement of the initiative is known to be relevant with the measures of the 2002 DOC, on the point of maintaining cooperative measures. Another proving point that China highly considers the conflict management policies of ASEAN in the matter of the South China Sea dispute.

Another example of ASEAN's success in instilling cooperative values in the South China Sea dispute is how China is choosing the option to continue negotiations on the COC (Code of Conduct in the South China Sea). Proposed by the Philippines after China's occupation of the Mischief Reef in 1995, the COC was planned to include measures of 'mutual restraint and conduct of activities' in regards to the South China Sea. As it would be legally binding, China and ASEAN were only able to conclude a non-binding agreement taking in the form of DOC in 2002 (ASEAN, 2002). Several attempts have been made by ASEAN to continue the negotiations from 
the implementation of the DOC, to the eventual draft of the COC that would legally bind all claimant states. Numerous attempts was the 2005 establishment of the Joint ASEAN-China Working Group (JWG), and the 'Six-Basic Principles on the South China Sea' as a result of Indonesia's Marty Natalegawa's shuttle diplomacy in 2012 (Emmers, 2014). Needless to say, that the progress of the COC have been taking a significantly slow pace, and as stated by the Foreign Minister of China Wang Yi, that China is in no hurry to conclude the COC by insisting that the implementation of the DOC should be the priority, as it reflects confidence building measures among parties (Thayer, 2013). One thing that needs to be outlined here is that the negotiations of the COC have not completely failed. Despite ASEAN is showing a higher urgency in concluding the COC and China stalling and taking its time, this does not mean that the COC will not be concluded, this only means that just like any conflict resolutions, the COC will take time. But by ASEAN's urgent push to China on the COC, China now has implemented the priority of eventually embracing the overall concepts in the DOC, a form of China's reassurance that progress is still taking place, but on a pace that China would prefer it to be.

ASEAN should be given high credits for its ability to instill these cooperative values to China's actions in the South China Sea. With the voluntary option to do so, it is obvious that China does have choices to remain in a state of complete assertiveness and belligerence, or to start engaging with ASEAN's framework of conflict management. Another example of how ASEAN's values of cooperation and peaceful resolution is highly considered by China, is China's decision to withdraw the oil drilling rig (HYSY-981) placed 120 miles form Vietnam's coasts (Leaf, 2014). Though initially was placed in May 2014, the rig was withdrawal took place 2 months after that. Though responded with anger by the neighboring states of ASEAN, China did have a choice to continue the placement, and ignore the responses of ASEAN states. But China hesitated, and eventually withdrew, a clear form of self-restraint and willingness to compromise its hard lined position in the South China Sea.

\subsection{The Relevance of ASEAN's Multilateralism Despite of China's Preference over Bilateral Means of Conflict Resolution}

One of the most unique elements of ASEAN, is the concept of 'ASEAN Centrality.' The concept by definition refers to ASEAN being positioned at the center of the various regional organizations or initiatives established (Anthony, 2014). Besides the ASEAN Summit, these ASEAN-led regional institutional forums have been known to include discussions on the South China Sea dispute, with the most relevant forums including the ASEAN Regional Forum (ARF) and the ASEAN Defense Ministers Plus Arrangements (ADMM). But it is now justified to question the relevance of these institutions, as China has reiterated that both ASEAN and its regional institutions are not the relevant platforms to discuss those matters.

China in the case of South China Sea dispute resolutions has continuously vocalized a bilateral based approach to solve such disputes. The approach taken is known as the 'Dual-Track Approach,' which consists of: (1) handling of bilateral disputes by the countries directly concerned through negotiations, and (2) maintenance of peace through joint efforts of China and ASEAN members (Parameswaran, 2015). China's preference over bilateral means of conflict resolution is understandable, as China would be able to counter any potential $3^{\text {rd }}$ party sources to interfere with the conflicts, forcing them to shift their stance. This proves that ASEAN is feared and the need for China to comply with ASEAN's conflict management terms is high. Not in the meaning that ASEAN would be able to threaten China if compliances are not present, but ASEAN is seen as being able to internationalize the progress of the South China Sea disputes, gaining International exposure through the ASEAN-led regional institutions it centers. ARF for example is witness of US's eventual announcement of its interest in the South China Sea in 2010 (ICS, 2012), reflecting how such a forum can easily expose China, further pressuring the state.

Despite China's preference over bilateral conflict resolution negotiations, the very fact that China until the present time still engages with ASEAN-led institutions, and have yet to close any talks/negotiations on the COC, reflects the fact that China's bilateral based policy of conflict management is not absolute. China's interest in ASEAN's multilateralism is that it provides China with multiple choices of diplomatic avenues to seek negotiations from. Though eventually China has been vocal about the institution's irrelevance and continuously has stalled talks, the very fact that China is still engaging in these forums reflects that they have yet to completely closed efforts of negotiations and peaceful resolution of conflict.

\section{Conclusion}

This research aims to analyze the conflict management role of ASEAN in regards to the South China Sea dispute. With the existence of numerous academic literatures that undermines its ability, this research argues the opposite by claiming that ASEAN through its confidence building measures and cooperative values, have been able to 
ease tensions. Conflict management is not an easy task for a $3^{\text {rd }}$ actor of a conflict, especially for a regional organization. But ASEAN has proved that through various measures including to instill cooperative values and confidence building measures, and the relevance of its multilateralism policies, the organization is able to keep up with the fast paced dynamic in the South China Sea disputes. Therefore, ASEAN as the most prominent regional organization in the region, have yet to fail in their specific role in managing the conflict. Though the progress can be categorized as slow, but the very fact that China is willing to voluntarily be parties of ASEAN's conflict management arrangements such as the TAC and DOC, and that essential negotiations of the COC are still running, only proves of the difficulty level that ASEAN would have to face in the upcoming future, not of its failure.

\section{References}

Anthony, M. C. (2014). Understanding ASEAN's Centrality: Bases and Prospects in an Evolving Regional Architecture. The Pacific Review, 27(4), 563-584.

ASEAN (Association of Southeast Asian Nations). (2002). Declaration on the Conduct of parties in the South China Sea: Adopted by the Foreign Ministers of ASEAN and the People's Republic of China at the $8^{\text {th }}$ ASEAN Summit in Phnom Penh, Cambodia.

ASEAN (Association of Southeast Asian Nations). (2005). Text of the Treaty of Amity and Cooperation in Southeast Asia and Related Information, 1-31.

ASEAN (Association of Southeast Asian Nations). (2011). Chairman's Statement of the $14^{\text {th }}$ ASEAN-China Summit, Bali, Indonesia, 18 November 2011, 1-4.

Ba, A. (2014). Managing the South China Sea Disputes: What can ASEAN Do? In M. Hiebert, P. Nguyen, \& G. B. Poling (Eds.), Perspectives on the South China Sea; Diplomatic, Legal, and Security Dimensions of the Dispute (pp. 2-13). US: CSIS.

Campbell, K., \& Andrews, B. (2013). Explaining the US 'Pivot' to Asia. The Asia Group, August, 1-9.

Chalk, P. (2014). Rebuilding While Performing; Military Modernization in the Philippines. Australian Strategic Policy Institute, 1-24.

Chen, H.-Y. (2014). Territorial Disputes in the South China Sea Under the San Fransisco Peace Treaty. Issues \& Studies, 50(3), 169-196.

Collinson, G., \& Roberts, C. B. (2015). The role of ASEAN. National Security College ANU, 35-39.

Dutton, P. A. (2013, March). The Sino-Philippine Maritime Row: International Arbitration and the South China Sea. Center for a New American Security, 1-9.

Emmers, R. (2010). The Changing Power Distribution in the South China Sea: Implications for Conflict $\begin{array}{llll}\text { management and } & \text { Avoidance. }\end{array}$ http://dx.doi.org/10.1177/0032318710381519

Emmers, R. (2014). Indonesia's role in ASEAN: A Case of Incomplete and Sectorial Leadership. The Pacific Review, 27(4), 543-559. http://dx.doi.org/10.1080/09512748.2014.924230

Emmers, R. (2015). The US Rebalancing Strategy: Impact on the South China Sea. ANU National Security College, 41-44.

Fravel, M. T. (2011). China's Strategy in the South China Sea. Contemporary Southeast Asia, 33(3), 293. http://dx.doi.org/10.1355/cs33-3b

Hooper, M. R. (2015). Before and After: The South China Sea Transformed. Retrieved from $\mathrm{http}: / /$ amti.csis.org/before-and-after-the-south-china-sea-transformed/

ICS (International Crisis Group). (2012). Stirring up the South China Sea, 4-38.

Jinming, L. (2012). Behind the Dotted Line on the Chinese Map of the South China Sea. CIR, Nov/Dec, 287-295.

Keck, Z. (2014). Don't Blame US Pivot for South China Sea Row: China-Not the U.S. Pivot-is Causing Tensions in the South China Sear Retrieved from http://thediplomat.com/2014/08/dont-blame-us-pivot-for-south-china-sea-row/

Lake, D. A., \& Morgan, P. M. (1997). Regional Orders: Building Security in a New World. State College: Pennsylvania State University Press, 11-16. 
Leaf, P. J. (2014). Learning from China's Oil Rig Standoff with Vietnam. Retrieved from $\mathrm{http} / /$ thediplomat.com/2014/08/learning-from-chinas-oil-rig-standoff-with-vietnam/

Parameswaran, P. (2015). China's Plan for ASEAN-China Maritime Cooperation. Retrieved from $\mathrm{http} / /$ thediplomat.com/2015/04/chinas-plan-for-asean-china-maritime-cooperation/

Parameswaran, P. (2015). The Challenge to China's South China Sea Approach. Retrieved from $\mathrm{http} / /$ thediplomat.com/2015/04/the-challenge-to-chinas-south-china-sea-approach

Rahim, M. A. (2002). Toward a Theory of Managing Organizational Conflict. The Journal of Conflict Management, 13(3), 206-235.

Ramsbotham, O., Woodhouse, T., \& Miall, H. (2011). Contemporary Conflict Resolution. UK: Polity Press, 31.

Reuters. (2015). South China Sea: China Placing Mobile Artillery on Reclaimed Island, US Says. Retrieved from http://www.abc.net.au/news/2015-05-29/us-says-china-has-placed-mobile-artillery-in-south-china-sea/6508 448

Severino, R. C. (n. d.). ASEAN and the South China Sea. Security Challenges, 6(2), 37-47.

Thayer, C. A. (2013). ASEAN, China and the Code of Conduct in the South China Sea. SAIS Review, 33(2), 75-84. http://dx.doi.org/10.1353/sais.2013.0022

US Department of State. (2014). Limits in the Seas; Maritime Claims in the South China Sea. Office of Ocean and Polar Affairs Bureau of Oceans and International Environmental and Scientific Affairs, 1-6.

Wee, S.-L., \& Brunnstrom, D. (2015). China Says U.S. South China Sea Actions 'Irresponsible, Dangerous.' Retrieved

from

http://www.reuters.com/article/2015/05/22/us-usa-china-southchinasea-idUSKBN0O70MO20150522

\section{Copyrights}

Copyright for this article is retained by the author(s), with first publication rights granted to the journal.

This is an open-access article distributed under the terms and conditions of the Creative Commons Attribution license (http://creativecommons.org/licenses/by/3.0/). 